http://dx.doi.org/10.1590/0370-44672018720060

\author{
Rodrigo Augusto Nunes ${ }^{1,3}$ \\ http://orcid.org/0000-0002-6613-1551 \\ Giorgio de Tomi ${ }^{2,4}$ \\ https://orcid.org/0000-0002-7836-1389 \\ Bladen Allan ${ }^{1,5}$ \\ http://orcid.org/0000-0001-9169-6290 \\ Erbertt Barros Bezerra ${ }^{2,6}$ \\ https://orcid.org/0000-0002-4303-6201 \\ Ranyere Sousa Silva ${ }^{2,7}$ \\ https://orcid.org/0000-0003-1034-9495 \\ ${ }^{1} Y a m a n a$ Gold Inc - Technical Services, \\ Toronto - Ontario - Canada
}

${ }^{2}$ Universidade de São Paulo - USP,

Departamento de Engenharia de Minas e Petróleo,

São Paulo - São Paulo - Brasil.

E-mails: ${ }^{3}$ rodrigo_anunes@hotmail.com, ‘gdetomi@usp.br, ${ }^{5}$ bladenallan@gmail.com, ${ }^{6}$ erberttbarros@gmail.com, ${ }^{7}$ ranyere.eng@gmail.com

\section{Introduction}

The strategic planning of a mine is a crucial step for the success of mining companies, since it provides the necessary information for the decision-making process concerning the development of the deposit (Silva, 2008). Therefore, in terms of strategic mine planning, it is important that the uncertainty related to the orebody is properly quantified, assessed, and managed (Godoy, 2018). For the preparation of the strategic mine plan, it is necessary to use models and data that are often estimated independently.

The technological model presented in this manuscript, aims to solve the disconnected and many times, inaccurate view of the deposit. This new approach consolidates the different data used to gain a better understanding of the geological, mine planning and processing data of the project. Lund and Lamberg (2014) state

\title{
An integrated pit-to-plant approach using technological models for strategic mine planning of copper and gold deposits
}

\begin{abstract}
The strategic mine plan is a crucial step for the success of mining companies, and for its development, it is necessary to use a number of inter-related variables that are usually estimated independently. These variables include operational data that is traditionally isolated in information islands between the different departments in the mine or they are consolidated into individual models. This reduces the holistic view of the deposit, thereby causing a negative impact on the results of the strategic planning itself. In order to improve the process and to maximize the production and/or value of a mining project, there needs to be an integration of the geology, the mine plan, the processing and the geometallurgy data. In order to accomplish this, a new methodology is proposed for the creation of a technological model. This model can be interpreted as the consolidation of the different models required for a better understanding of the geological and technical information of the deposit. This concept was developed and applied at a copper and gold mine site located in Brazil. Based on the evaluation of different blasting and mill productivity scenarios through a pit-to-plant approach, it was possible to obtain operational short-term gains such as a $10.7 \%$ increase in the plant production rate and a $2.2 \%$ increase in the crusher's feed rate with little or no capital investment.
\end{abstract}

keywords: strategic planning, pit-to-plant, technological model, copper and gold, geometallurgy.

that the construction of technological models can reduce operational risks and could help to optimize the production, taking into account sustainability and socio-economic factors.

The data that is being referred to in this study includes the resource and structural models, the geometallurgical model, the cost model and the operating Selective Mining Unit (SMU) model, which is the smallest volume of material that the classification of ore and waste can be determined (Sinclair and Blackwell, 2002).

The Geometallurgical model, a component of the technological model, allows for a better understanding of the ore characteristics. The importance of this increased knowledge base is that by knowing the strength, structure, and grade, there are adjustments that can be made to the crushing, grinding, and floatation processes (La Rosa et al., 2014).

Gomes et al. (2016) used a geometallurgical model to support an economic study considering reserve volumes, product quality and operational cost. From the model a remarkable gain was obtained in the iron ore reserve and in an operation cost reduction. Its use is also essential for strategic mining planning for mines that seek to optimize the use of mining resources over the life of mine (Philander and Rozendaal, 2014). Navarro et al. (2018) incorporated the geometallurgical modeling in long-term planning and confirmed its great impact on the life of mine.

As noted by Augustin et al. (2017) the models should continually be updated whenever possible, by way of additional exploratory drill holes, to ensure that a greater detail of accuracy is achieved. Nadolski et al. (2015) complement that 
these models require constant adjustment, with the insertion of the geotechnical, geological, metallurgical and other operational data from the plant, which will also serve to calibrate predictive models.

The development process for the preparation of the technological model in question, used the work undertaken at a large-scale open pit copper and gold mine of sulfide ore located in Brazil, as a

\section{Materials and methods}

As a starting point for the model, the different unit operations of the mine and plant were characterized. Blasting designs, mine and plant sampling, and reference. The process includes crushing, grinding, and flotation. The saleable product is a copper-gold concentrate.

In the studied mine, the ore comes from different mining faces feeding the plant at the same time. The technological model created, tracked the ore characteristics back to its original mining face. One of the main objectives of the technological model was to determine the plant performance by the ore domain on an industrial scale and, to adjust the blasting parameters aiming to increase the plant throughput but keeping the metallurgical recoveries at similar or higher levels. This concept of pit-to-plant optimization has been in use at other mine sites around the world where different processes of integration and optimization were applied (Jankovic and Valery, 2011).

operational testing were carried out. The data obtained was used to develop the specific models for the prediction processes of blasting, crushing, and grind-

ing. These models were the basis of the construction of the technological model. Figure 1 summarizes the components of the technological model.

\begin{tabular}{l}
\hline Resource and Structural Model \\
- Structual Geology \\
- Lithology \\
- Alterations \\
- Grades \\
- Geotechnical Parameters for mine design \\
\hline Geometallurgical Model \\
- Metallurgical Recoveries \\
- Hardness \\
- Plant Productivity for different lithostructural domains \\
Cost Modeland SMU \\
- Operational cost estimates for the mine, plant, etc by lithostructural \\
domains \\
- Creation of SMUs based on planned mining and dilution methods
\end{tabular}

The methodology used for the preparation of the technological model is based on the following steps:

- Characterization and delineation of areas based on their geological structure, strength, and correlation with their lithological and structural domains.

- Establishing operating restrictions such as the stability of benches, the presence of water, SMU size, ore
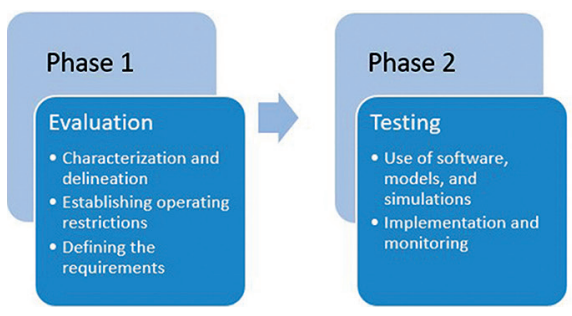

The first step required an audit to be carried out during the drilling and blasting operations. This was necessary in order to obtain data, pictures, and other observations that are required to provide enough information for the creation of the fragmentation models. Once the information is obtained, the blasting techniques can be tailored to the rock characteris- dilution allowance, the blast pile characteristics, the size of the equipment, and the size/power of the crushers/mills, in addition to any other bottlenecks in the process.

- Defining the main requirements of the subsequent steps to plan for each geological domain in order to meet their specific requirements.

- Use of software, mathematical models, and process simulation.

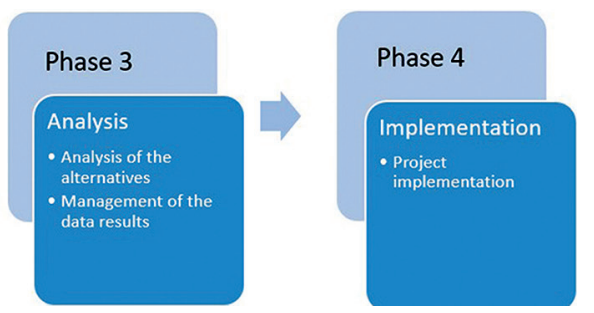

tics, which will allow for substantial improvements in the downstream operations (Kanchibolta et al., 2015).

Simulations of the blasting plan were executed with both the soft and hard ore. Various parameters were changed depending on the simulation. Compared to the base case these variations included, a slight increase in bench height, an increase in hole
Figure 1

Components of the Technological Model.

- Implementation and monitoring of the defined operational strategy (suitable plans for each domain followed by the ideal adjustment for the crushing and grinding cycle).

- Analysis and management of data and results.

- Project implementation and maintaining the benefits obtained.

The above methodology is simplified in the Figure 2.

Figure 2

Project flow chart.

diameter, a change in spacing, sub drilling, hole depth, stemming, and an increase in the column charge.

In the second phase of the preparation of the technological model, laboratory tests, image analyses, data processing, and mathematical models were consolidated. In order to optimize the ROM fragmentation from the mine blasting, a fragmentation 
model was developed. This model is sensitive to the main parameters that affect the blasting performance. The

fragmentation model was then calibrated with the data obtained from the observed blasting during the audit process and used to predict changes in the particle size distribution of the ROM.

\section{Fragmentation measurement using image analysis}

Particle size distribution of the ROM is one of the parameters used in calibrating the fragmentation model. Prior studies of operations around the world have indicated

Figure 3

Example of a rendered image from the Split-Desktop software.

\section{Blast Tracking}

Electronic tags were used to track the blasted material, enabling the verification of when the material enters the crushing/ grinding cycle. Therefore, the complete sampling of the plant could be performed using the audited blasted material. Samples

Figure 4

The Reinforced Electronic Tag and the antenna above the conveyor belt.

In total, 274 electronic tags were used in the survey data. They were put in the stem, in the piles formed after detonation, and in the feed of each primary crusher. In order to obtain the data for calibrating the mathematical

Table 1

List of the circuit comminution equipment.

that image analysis is a good and practical method for this purpose. Photographs of the piles formed after the verified blasting and primary crushing were processed using

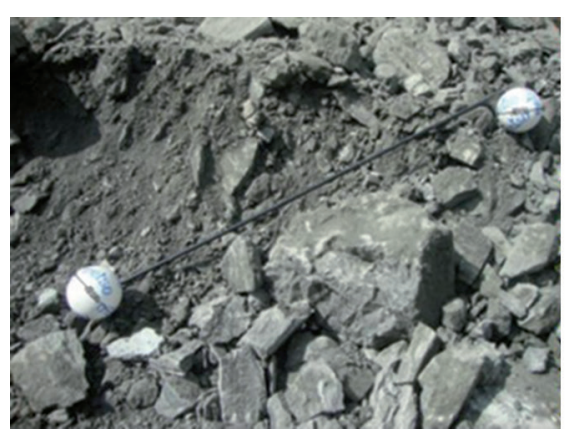

collected from the conveyor belts and the main streams for laboratory tests determined the breaking characteristics of the material. Specific models were developed for the blasting, crushing, grinding, and classification processes by using the audit-
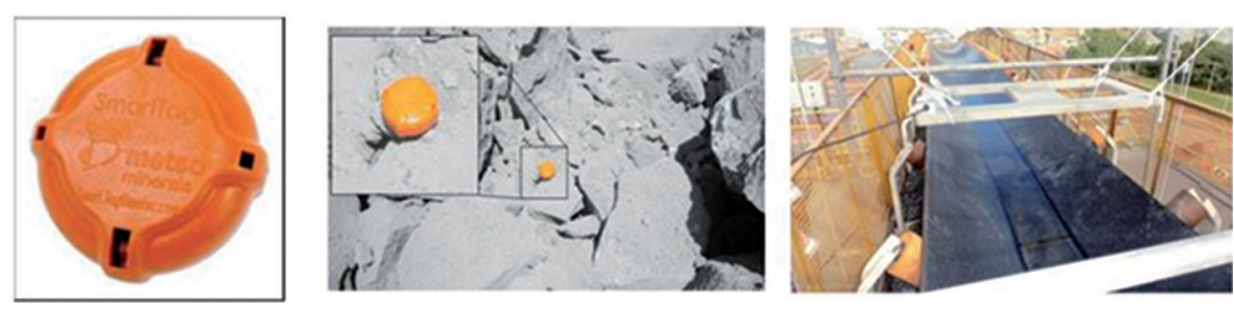

models for the different equipment in the circuit, sampling was performed in the crushing and grinding circuit. Operational data was also collected during the sampling to determine the production rates and power consumption of the Split-Desktop software (Split Engineering, 2017). Each image contains an object for scale. For this project, two Styrofoam balls were used and are pictured in Figure 3.

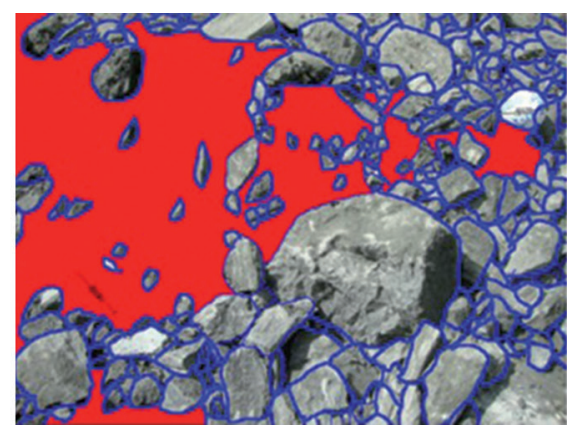

ed blast data, sampling, and testing. Figure 4 shows the electronic tag with a diameter of $60 \mathrm{~mm}$ and a height of $30 \mathrm{~mm}$ used in the study as well as the typical installation of the electronic tag system with an antenna positioned above the conveyor belt. each piece of equipment listed in Table 1. The sampling points are shown in the flowchart in Figure 5. Once the sampling was complete, the data was balanced and modelling was performed in the JKSimMet software (JKTech, 2014).

\begin{tabular}{|c|c|}
\hline Equipment & Description \\
\hline $\begin{array}{l}\text { Primary } \\
\text { Crushers }\end{array}$ & $\begin{array}{l}\cdot \text { MMD Sizer S100-20, 400kW } \\
\quad \cdot \text { Metso C160, 220kW }\end{array}$ \\
\hline SAG Mill & $\begin{array}{c}1 \text { mill with an internal diameter of } 10.01 \mathrm{~m} \text { and } 4.95 \mathrm{~m} \text { of EGL, } 11000 \mathrm{~kW} \text {, } \\
10.34 \mathrm{rpm}\end{array}$ \\
\hline Pebble Crusher & 2 Metso HP800, 600kW \\
\hline Ball Mill & $\begin{array}{l}1 \text { mill with an internal diameter of } 7.09 \mathrm{~m} \text { and } 11.94 \mathrm{~m} \text { of EGL, } 12500 \mathrm{~kW} \text {, } \\
12.19 \mathrm{rpm}\end{array}$ \\
\hline Cyclones & $\begin{array}{c}\text { Cluster SAG: } 6 \text { Multotec HC900-L20 cyclones, with a } 360 \mathrm{~mm} \text { equivalent entry } \\
\text { diameter, a } 340 \mathrm{~mm} \text { vortex, and a } 170 \mathrm{~mm} \text { apex } \\
\text {-Cluster Ball: } 8 \text { Krebs GMAX } 33 \text { cyclones, with a } 390 \mathrm{~mm} \text { equivalent entry diam- } \\
\text { eter, a } 305 \mathrm{~mm} \text { vortex, and a } 180 \mathrm{~mm} \text { apex }\end{array}$ \\
\hline
\end{tabular}




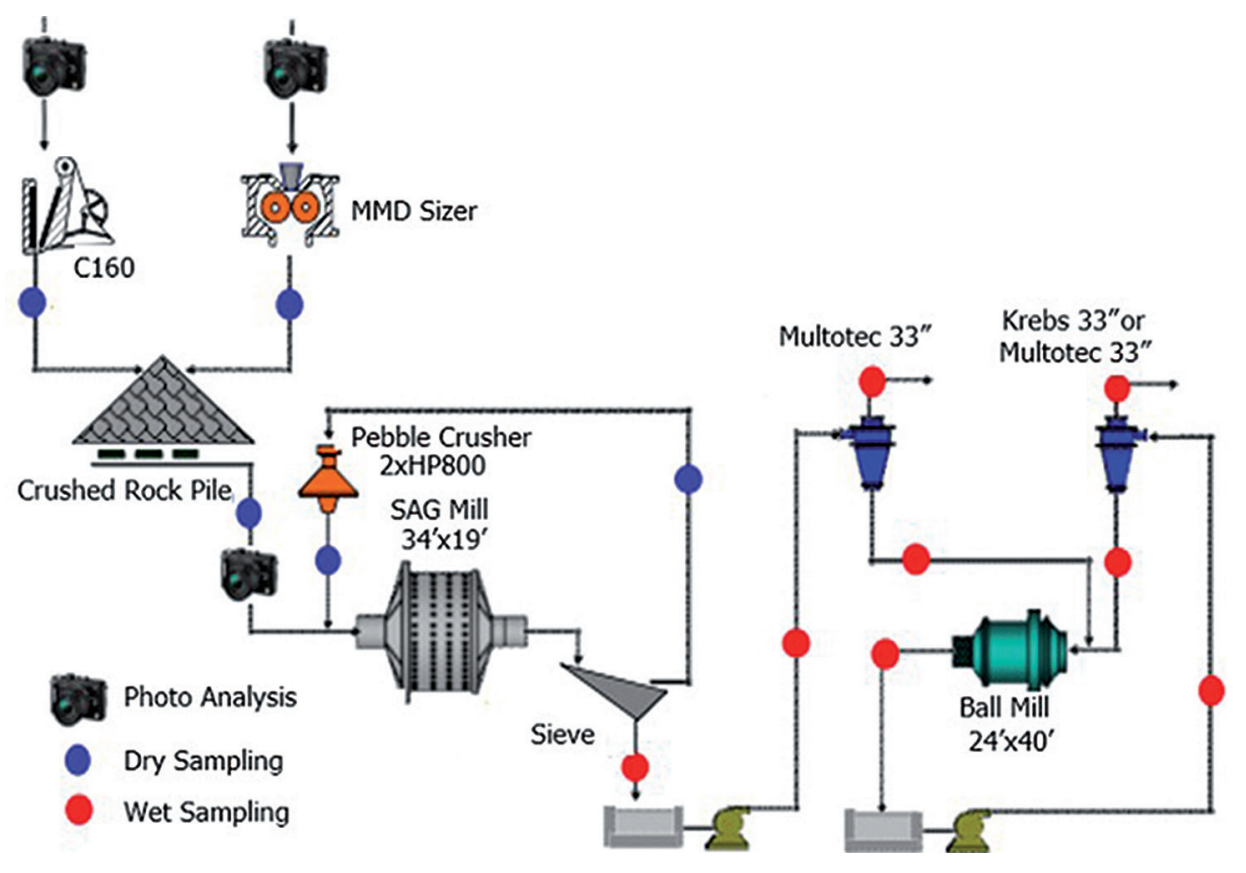

After the completion of the mass balancing, the mathematical models of all the processing units were calibrated according to the Anderson and Awachie model for the primary crushers in the JKSimMet software version 6.0 (JKTech, 2014) and Whiten (Whiten and White, 1979). The objective was to model the grinding cycle at the time of sampling. The perfect blend model and the variable rate model

\section{Test results and discussion}

In total there were 24 blasting simulations carried out. Eleven of those simulations were performed on soft ore, and the remain-

ing thirteen, which are shown below, were carried out on hard ore. Once the simulations were completed, one of the thirteen
Figure 5

Sampling points in the grinding cycle. Mass balance and adjustment models.

account were the characteristics of the ore, the dimensions of the equipment, and the information related to the operation during sampling, which includes the load and speed levels of the mills, the energy consumption, and the operating pressure of the cyclones. Historical data was also considered to ensure that the results are consistent and that they represent the operation of the cycle as accurately as possible.

\begin{tabular}{|c|c|c|c|c|c|c|c|c|c|c|c|c|c|c|c|}
\hline \multirow{2}{*}{\multicolumn{2}{|c|}{ Long Term - Hard Ore }} & \multirow{2}{*}{ Base Case } & \multicolumn{13}{|c|}{ Sim LPD } \\
\hline & & & 1 & 2 & 3 & 4 & 5 & 6 & 7 & 8 & 9 & 10 & 11 & 12 & 13 \\
\hline \multicolumn{16}{|l|}{ Dimensions } \\
\hline Bench Height & $\mathrm{m}$ & 9.9 & 10.0 & 10.0 & 10.0 & 10.0 & 10.0 & 10.0 & 10.0 & 10.0 & 10.0 & 10.0 & 10.0 & 10.0 & 10.0 \\
\hline \multirow{2}{*}{ Hole Diameter } & pol & 6.75 & 10 & 10 & 10 & 10 & 10 & 10 & 10 & 9 & 9 & 9 & 9 & 9 & 9 \\
\hline & $\mathrm{mm}$ & 161 & 238 & 238 & 238 & 238 & 238 & 238 & 238 & 214 & 214 & 214 & 214 & 214 & 214 \\
\hline Burden & $\mathrm{m}$ & 3.9 & 4.8 & 4.6 & 4.3 & 4.1 & 3.8 & 3.6 & 3.6 & 4.3 & 4.1 & 3.9 & 3.7 & 3.4 & 3.2 \\
\hline Spacing & $\mathrm{m}$ & 4.7 & 5.6 & 5.3 & 5.0 & 4.7 & 4.5 & 4.2 & 4.1 & 5.0 & 4.7 & 4.5 & 4.2 & 4.0 & 3.7 \\
\hline Subdrilling & $\mathrm{m}$ & 1.20 & 1.30 & 1.30 & 1.30 & 1.20 & 1.20 & 1.10 & 1.10 & 1.30 & 1.20 & 1.20 & 1.10 & 1.00 & 1.00 \\
\hline Hole Depth & $\mathrm{m}$ & 11.1 & 11.3 & 11.3 & 11.3 & 11.2 & 11.2 & 11.1 & 11.1 & 11.3 & 11.2 & 11.2 & 11.1 & 11.0 & 11.0 \\
\hline Stem & $\mathrm{m}$ & 2.80 & 3.40 & 3.40 & 3.40 & 3.40 & 3.40 & 3.40 & 3.40 & 3.10 & 3.10 & 3.10 & 3.10 & 3.10 & 3.10 \\
\hline \multicolumn{16}{|l|}{ Explosives } \\
\hline Column Charge & & \begin{tabular}{|c|} 
Pumped \\
Emulsion
\end{tabular} & E.B. 70 & E.B. 71 & E.B. 72 & E.B. 73 & E.B. 74 & E.B. 75 & E.B. 76 & E.B. 77 & E.B. 78 & E.B. 79 & E.B. 80 & E.B. 81 & E.B. 82 \\
\hline \multirow[t]{2}{*}{ Column Load Density } & $t / m^{3}$ & 1.20 & 1.20 & 1.20 & 1.20 & 1.20 & 1.20 & 1.20 & 1.20 & 1.20 & 1.20 & 1.20 & 1.20 & 1.20 & 1.20 \\
\hline & $\mathrm{kg}$ & 202 & 422 & 422 & 422 & 417 & 417 & 412 & 412 & 355 & 351 & 351 & 347 & 342 & 342 \\
\hline \multirow[t]{2}{*}{ Column Charge } & $\mathrm{m}$ & 8.3 & 7.9 & 7.9 & 7.9 & 7.8 & 7.8 & 7.7 & 7.7 & 8.2 & 8.1 & 8.1 & 8 & 7.9 & 7.9 \\
\hline & $\mathrm{kg} / \mathrm{m}$ & 24.4 & 53.5 & 53.5 & 53.5 & 53.5 & 53.5 & 53.5 & 53.5 & 43.3 & 43.3 & 43.3 & 43.3 & 43.3 & 43.3 \\
\hline \multicolumn{16}{|l|}{ Blasting Parameters } \\
\hline Blasted Volume & $\mathrm{m}^{3}$ & 182 & 269 & 244 & 215 & 193 & 171 & 151 & 148 & 215 & 193 & 176 & 155 & 136 & 118 \\
\hline Rock Density & $t / m^{3}$ & 2.7 & 2.7 & 2.7 & 2.7 & 2.7 & 2.7 & 2.7 & 2.7 & 2.7 & 2.7 & 2.7 & 2.7 & 2.7 & 2.7 \\
\hline Blasted Mass & $\mathrm{t}$ & 491 & 726 & 658 & 581 & 520 & 462 & 408 & 399 & 581 & 520 & 474 & 420 & 367 & 320 \\
\hline \multirow[t]{2}{*}{ Specific Drilling } & $\mathrm{m}^{3} / \mathrm{m}$ & 18.4 & 26.9 & 24.4 & 21.5 & 19.3 & 17.1 & 15.1 & 14.8 & 21.5 & 19.3 & 17.6 & 15.5 & 13.6 & 11.8 \\
\hline & $t / m$ & 49.6 & 72.6 & 65.8 & 58.1 & 52.0 & 46.2 & 40.8 & 39.9 & 58.1 & 52.0 & 47.4 & 42.0 & 36.7 & 32.0 \\
\hline \multirow[t]{2}{*}{ Powder Factor } & $\mathrm{g} / \mathrm{t}$ & 412 & 582 & 642 & 728 & 802 & 903 & 1009 & 1033 & 612 & 674 & 741 & 826 & 932 & 1071 \\
\hline & $\mathrm{kg} / \mathrm{m}^{3}$ & 1.11 & 1.57 & 1.73 & 1.96 & 2.16 & 2.44 & 2.72 & 2.79 & 1.65 & 1.82 & 2.00 & 2.23 & 2.52 & 2.89 \\
\hline \multicolumn{16}{|l|}{ ROM Specifications } \\
\hline P100 & $\mathrm{mm}$ & 1092 & 933 & 861 & 764 & 724 & 637 & 598 & 595 & 816 & 770 & 706 & 661 & 593 & 533 \\
\hline P80 & $\mathrm{mm}$ & 379 & 310 & 287 & 258 & 241 & 217 & 201 & 199 & 282 & 264 & 244 & 226 & 204 & 184 \\
\hline Passing $10 \mathrm{~mm}$ & $\%$ & 11.9 & 15.6 & 16.9 & 18.7 & 20.2 & 22.2 & 24.2 & 24.6 & 13.3 & 17.7 & 19.0 & 20.7 & 22.8 & 25.5 \\
\hline
\end{tabular}

The use of electronic tags in the blasted material proved to be effective in tracking the ore from the mine to the plant and assured that the audited blasted material was fed to the plant during sampling. During the 34-hour monitoring period, 131 (base case) was selected to be applied to the blasting plan in the field. The hard ore simulations are presented in the Table 2 below.
Table 2

Blasting scenarios for hard ore.

electronic tags out of the 274 were detected. The spatial coordinates of each detected electronic tag are shown in Figure 6. 
Figure 6

The positioning of each electronic tag detected.

After the plant sampling was complete and the experimental data was collected, the model could be created. The mass balancing results compared well to the experimental

Table 3

Experimental and modeled data from the main streams.

The results of the rock blasting simulations demonstrated the importance of improving the results of fragmentation, especially when analyzing the productivity of an integrated comminution process for harder lithology. There was a $37 \%$ reduction in the production rate of the SAG (2026 to $1269 \mathrm{t} / \mathrm{h}$ ) when the circuit supply consisted only of hard material. Under this same condition, increasing the powder factor to 2.78 $\mathrm{kg} / \mathrm{m} 3$ resulted in an increase in the mill's productivity by $10.7 \%$. This result directly relates to the finer particle size distribution obtained from

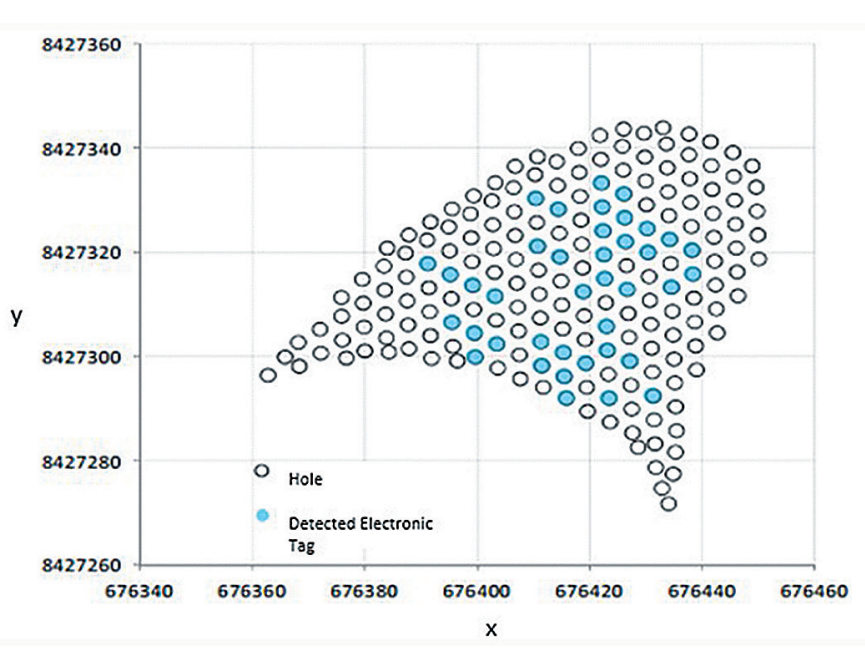

data, indicating that the sampling data is valid for further analysis. In general, the models developed in JKSimMet (JKTech, 2014) were well adjusted with respect to the data, and

are considered appropriate for longterm simulation studies that are to be used in strategic mine planning. The experimental and modeled data can be compared in Table 3 below.

\begin{tabular}{|c|c|c|c|c|c|c|c|}
\hline \multicolumn{2}{|c|}{ Mine Modelling } & \multicolumn{2}{|c|}{ Solids, $\mathrm{t} / \mathrm{h}$} & \multicolumn{2}{|c|}{$\mathrm{P} 80, \mathrm{~mm}$} & \multicolumn{2}{|c|}{ \% Solids } \\
\hline & & Exp & Mod & Exp & Mod & Exp & Mod \\
\hline \multirow[b]{2}{*}{ SAG } & feed & 2026 & 2026 & 157.6 & 157.6 & 94.6 & 94.6 \\
\hline & Prod. & & 2484 & & 8.73 & & 70 \\
\hline \multirow[b]{2}{*}{ Sieve SAG } & $\mathrm{O} / \mathrm{S}$ & 458 & 458 & 54.2 & 51.7 & 98.5 & 98.9 \\
\hline & $\mathrm{U} / \mathrm{s}$ & & 2026 & 1.351 & 1.21 & 65.2 & 65.7 \\
\hline Pebble Crusher & Prod. & & 458 & 19.1 & 19.4 & 99 & 98.9 \\
\hline \multirow{3}{*}{ Cyclone SAG } & feed & & 2026 & 0.836 & 1.21 & 46.1 & 47.6 \\
\hline & $\mathrm{O} / \mathrm{f}$ & & 768 & 0.196 & 0.196 & 35.3 & 32.8 \\
\hline & $U / f$ & & 1258 & 2.593 & 2.62 & 64.7 & 65.7 \\
\hline \multirow[t]{2}{*}{ Ball Mill } & feed & & 5411 & & 1.68 & & 70 \\
\hline & Prod. & & 5411 & 0.803 & 0.811 & 72.3 & 70 \\
\hline \multirow{3}{*}{ Ball Cyclone } & feed & & 5411 & 2.625 & 0.811 & 71.9 & 61.5 \\
\hline & $\mathrm{O} / \mathrm{f}$ & & 1258 & 0.177 & 0.177 & 34.4 & 37 \\
\hline & $U / f$ & & 4153 & 2.187 & 1.333 & 76.5 & 76.9 \\
\hline
\end{tabular}

the increased energy in the rocks from the blasting.

The SAG cycle improves with an increase in the load (the percent of mill volume occupied by media plus voids) from $8 \%$ mill balls (measured after grinding) to $10-13 \%$ mill balls. These changes allowed the grinding circuit to increase to within $2-4 \%$ of the productivity achieved with the largest open area. In order to better utilize the installed power of the pebble crushers, SAG mill grates with larger openings were installed. When comparing the scenario to the finer ROM, the simulation resulted in a $14 \%$ increase in pebble generation, while the feed rate increased by $2.2 \%$. It is important to note that by increasing the opening of the grate, the grate life is shortened. Therefore, it was suggested to find alternatives in order to minimize the wear on the grate.

As an outcome of this methodology, the technological model has shown to be adherent to the plant results and operational data collected after many reconciliation processes. This methodology is still being used at the mine, which constantly updates the model with the new input data. 
The results of the simulated scenarios with different mill loads are presented in Table 4.

Table 4

Simulated scenarios with the optimization of the SAG.

\begin{tabular}{|c|c|c|c|c|c|c|c|c|}
\hline \multirow{2}{*}{$\begin{array}{l}\text { Simulated Scenarios } \\
\text { SAG Optimization }\end{array}$} & \multirow[b]{2}{*}{ Units } & \multirow{2}{*}{$\begin{array}{l}\text { Sampling } \\
\text { Base Case }\end{array}$} & \multicolumn{2}{|c|}{$100 \%$ Hard Ore } & \multirow{2}{*}{$\begin{array}{l}\text { CP F } 07 \\
\text { CP D } 07\end{array}$} & \multirow{2}{*}{\begin{tabular}{c|}
$3.5^{\prime \prime}$ Grates \\
$12 \%$ Open Area
\end{tabular}} & \multicolumn{2}{|c|}{ Ball load } \\
\hline & & & Base Case & PF 2.78 & & & $10 \%$ & $13 \%$ \\
\hline Production Rate & $t / h$ & 2026 & 1269 & 1405 & 2530 & 2585 & 2630 & 2690 \\
\hline$\Delta$ in Production Rate & $\%$ & & & 10.7 & & 2.2 & 3.9 & 6.3 \\
\hline F80 of Feed & $\mathrm{mm}$ & 157.6 & 142.4 & 102.1 & 102.7 & 102.7 & 102.7 & 102.7 \\
\hline Feed Passing Through $12.5 \mathrm{~mm}$ & $\%$ & 31.7 & 16.9 & 29.8 & 42.6 & 42.6 & 42.6 & 42.6 \\
\hline Power Consumed by the SAG & $\mathrm{kW}$ & 9053 & 9053 & 9053 & 9053 & 9053 & 9560 & 10400 \\
\hline Pebble Production & $t / h$ & 458 & 412 & 404 & 534 & 610 & 577 & 491 \\
\hline Power Consumed by the Pebble Crusher & $\mathrm{kW}$ & 690 & 658 & 640 & 770 & 854 & 804 & 684 \\
\hline Sieve Undersize P80 & $\mathrm{mm}$ & 1.21 & 1.55 & 1.48 & 1.29 & 1.44 & 1.56 & 1.64 \\
\hline Partition of the SAG cyclone & $\%$ & 39.7 & 40.1 & 33 & 38.6 & 39 & 38.4 & 37.6 \\
\hline Cyclone SAG Overflow of P80 & $\mathrm{mm}$ & 0.196 & 0.179 & 0.200 & 0.197 & 0.191 & 0.194 & 0.199 \\
\hline Cyclone SAG underflow of P80 & $\mathrm{mm}$ & 2.615 & 3.610 & 2.894 & 2.808 & 3.104 & 3.174 & 3.113 \\
\hline Ball Mill Power Consumption & kW & 11201 & 11201 & 11201 & 11201 & 11201 & 11201 & 11201 \\
\hline Rolling Charge & $\%$ & 330 & 287 & 369 & 327 & 329 & 340 & 353 \\
\hline Ball Cyclone Overflow of P80 & $\mathrm{mm}$ & 0.177 & 0.176 & 0.188 & 0.208 & 0.214 & 0.219 & 0.224 \\
\hline Grinding Circuit Product of P80 & $\mathrm{mm}$ & 0.184 & 0.177 & 0.192 & 0.204 & 0.205 & 0.209 & 0.214 \\
\hline Total Power Consumed & $\mathrm{kW}$ & 20994 & 20912 & 20894 & 21024 & 21108 & 21565 & 22285 \\
\hline Specific Energy Consumption & $\mathrm{kWh} / \mathrm{t}$ & 10.3 & 16.5 & 14.9 & 8.3 & 8.2 & 8.1 & 8.1 \\
\hline Operational WI & $\mathrm{kWh} / \mathrm{t}$ & 14.5 & 22.7 & 21.5 & 12.4 & 12.2 & 12.3 & 12.5 \\
\hline
\end{tabular}

\section{Conclusion}

The methodology for the implementation of the technological model proved to be a viable option in this scenario, and has the potential to be applied to different projects with similar grinding processes. For the studied mine, the technological model which was an outcome of the assessment was incorporated into the short and medium term mine planning schedules. It was formulated as a block model and was used together with the mine planning software. The different technological variables presented in this model enabled the engineers to simulate different blasting and plant productivity scenarios, supporting the decision making process for the development of the deposit. As a result, it is possible to improve the efficiency of the plant with little or no capital investment by optimizing the breaking and fragmenting mechanisms through blasting, crushing, and grinding. This resulted in:

- A reduction of the top size of the ROM, which allowed the primary crusher to operate with a higher feed rate by $2.2 \%$, a reduced opening, and to feed the SAG with a smaller top size.

- Operating the SAG with more fines $(<10 \mathrm{~mm})$ by increasing the powder factor to $2.78 \mathrm{~kg} / \mathrm{m}^{3}$, increased the plant production rate by $10.7 \%$ while using the same power.

\section{References}

AUGUSTIN, M., BONKEKA, M., PATRICK, M. Strategic mine planning approach applied to large scale copper open pit mines by comparing the impact of three different bloc models of the same deposit, on the Long Term Mine Plan. International Journal of Advanced Research in Engineering, v. 3, n. 2, p. 1-5, 2017.

GODOY, M. A Risk analysis based framework for strategic mine planning and design - method and application. Advances in Applied Strategic Mine Planning, p. 75-90, 2018.

GOMES, R. B., DE TOMI, G., ASSIS, P. A. Mine/Mill production planning based on a Geometallurgical Model. REM: Revista Escola de Minas, v. 69, n. 2, p. 213-218, 2016.

JANKOVIC, A., VALERY, W. New methodology to improve productivity of mining operations. In: BALKAN MINERAL PROCESSING CONGRESS, TURKEY, 14. v. 1, p. 557-565, 2011. (Conference).

JKTech. JKSimMet - Version 6.0 Steady State Mineral Processing Simulator. 
Brisbane, 2014.

KANCHIBOTLA, S. S., VIZCARRA, T. G., MUSUNURI, S. A. R., TELlO, S., HAYES, A., MOYLAN, T. Mine to mill optmisation at paddington gold operations. In: INTERNATIONAL CONFERENCE ON SEMI-AUTOGENOUS AND HIGH PRESSURE GRINDING TECHNOLOGY, 2015.

NADOLSKI, S., KLEIN, B., ELMO, D., SCOBLE, M. Cave-to-mill: a mine-to-mill approach for block caves mines. Mining Technology, v.124, p. 47-55, 2015.

NAVARRA, A., GRAMMATIKOPOULOS, T., WATERS, K. Incorporation of geometallurgical modelling into long-term production planning. Minerals Engineergin, v. 120, p. 118-126, 2018.

LA ROSA, D., RAJAVUORI, L., KORTENIEMI, J., WORTLEY, M. Geometallurgical modelling and ore tracking at Kittila Mine. In: OREBODY MODELLING AND STRATEGIC MINE PLANNING SYMPOSIUM, 2014.

LUND, C., LAMBERG, P. Geometallurgy - a tool for better resource efficiency. European geologist, v.37, p. 39 - 43, 2014.

NAGESWARARAO, K. A Generalised model for hydrocyclone classifiers. Proceedings of Australasian Institute of Mining and Metallurgy, v. 300, n. 2, p. 21, 1995.

PHILANDER, C., ROZENDAAL, A. A process mineralogy approach to geometallurgical model refinement for the Namakwa Sands heavy minerals operations, west coast of South Africa. Minerals Engineering, v. 65, p. 9-16, 2014.

SILVA, N. Metodologia de planejamento estratégico de lavra incorporando riscos e incertezas para a obtenção de resultados operacionais. 2008.

SINCLAIR, A., BLACKWELL, G. Applied mineral inventory estimation. United Kingdom: Cambridge University Press, 2002.

SPLIT ENGINEERING. Split-Desktop - Version 4.0. Retrieved from https://www. spliteng.com, 2017.

WHITEN, W. J., WHITE, M. E. Modeling and simulation of high tonnage crushing plants. In: INTERNATIONAL MINERAL PROCESSING CONGRESS, 12. São Paulo, p. 148-158, 1979.

Received: 2 May 2018 - Accepted: 19 November 2018. 